\title{
Risk factors associated with the presence of Mycobacterium bovis in macroscopic lesions suspected as being caused by bovine tuberculosis detected in slaughterhouses
}

\section{Fatores de risco associados à presença de Mycobacterium bovis em lesões macroscópicas suspeitas de serem causadas por tuberculose bovina detectada em matadouros}

Flávio Gomes Barcelos ${ }^{1}$; Taís Ramalho dos Anjos²; Leila Auxiliadora de Arruda Alencar3; Vinicius Silva Castro4; Adelino Cunha-Neto5; Fernanda Tavares Carvalho6; Mariano Martinez Espinosa7; Ricardo Cesar Tavares Carvalho8; Eduardo Eustáquio de Souza Figueiredo ${ }^{\text {* }}$

Highlights

Sex, breed, age, and livestock circuit were not different of other risk factors.

Sanitary slaughters has a positive effect in the post-mortem diagnosis

Intradermal tuberculin and molecular test potentiate the identification of M. bovis.

1 Student, Postgraduate Program of Animal Science, Faculty of Agronomy and Zootechnics, Universidade Federal de Mato Grosso, UFMT, Cuiabá, MT, Brazil. E-mail: barcelosvet@hotmail.com

2 Student, Postgraduate Program in Animal Bioscience, Faculty of Veterinary Medicine, Universidade de Cuiabá, UNIC, Cuiabá, MT, Brazil. E-mail: tranjos.vet@gmail.com

${ }^{3}$ Researcher, Faculty of Nutrition, Food Science and Technology Graduation, UFMT, Cuiabá, MT, Brazil. E-mail: leilaaalencar@gmail.com

${ }^{4}$ Researcher, Postgraduate Program of Animal Science, Faculty of Agronomy and Zootechnics, UFMT, Cuiabá, MT, Brazil., E-mail: viniciuscastro06@gmail.com

${ }^{5}$ Researcher, Faculty of Nutrition, UFMT, Cuiabá, MT, Brazil. E-mail: adeneto40@gmail.com

${ }^{6}$ Student, Postgraduate Program in Nutrition, Food and Metabolism, Faculty of Nutrition, UFMT, Cuiabá, MT, Brazil, and UNIC, Postgraduate Program in Animal Bioscience, Faculty of Veterinary Medicine, Cuiabá, MT, Brazil. E-mail: fefetavares_carvalho@hotmail.com

7 Prof., Institute of Exact and Earth Sciences, Department of Statistics, UFMT, Cuiabá, MT, Brazil. E-mail:marianomphd@ gmail.com

8 Prof., Postgraduate Program in Nutrition and Metabolism, Faculty of Nutrition, UFMT, Cuiabá, MT, Brazil, and UNIC, Postgraduate Program in Animal Bioscience, Faculty of Veterinary Medicine, Cuiabá, MT, Brazil. E-mail: ricardo_ carvalho88@hotmail.com

9 Prof., Postgraduate Program of Animal Science, Faculty of Agronomy and Zootechnics, UFMT, and Postgraduate Program in Nutrition, Food and Metabolism, Faculty of Nutrition, Cuiabá, MT, Brazil. E-mail: figueiredoredoeduardo@ ufmt.br

* Author for correspondence

Received: Aug.. 23, 2021 - Approved: Dez. 07, 2021 


\section{Abstract}

Mycobacterium bovis is a bacterium belonging to the Mycobacterium tuberculosis complex that causes tuberculosis in cattle and in other domestic and wild animals, as well as in humans. Disease control measures are carried out by slaughtering animals tested positive in the intradermal tuberculinization test and sanitation of their original living spaces, in addition to epidemiological surveillance carried out through the sanitary inspection of bovine carcasses in slaughterhouses. In the latter, official inspection services collect samples from macroscopic lesions suspected of bovine tuberculosis, which are then sent for laboratory analysis. Knowledge concerning the variables associated with the occurrence of $M$. bovis can aid in decision-making regarding control and disease eradication efforts. In this context, the aim of this study was to identify the risk factors for a positive $M$. bovis diagnosis in suspected bovine tuberculosis lesions obtained during epidemiological surveillance activities in the state of Mato Grosso, Brazil. A total of 105 suspicious lesions were analyzed using the Nested Polymerase Chain Reaction (nested q-PCR) method, of which 14 (13.33\%) tested positive for M. bovis. Univariate and bivariate statistical analyses indicated that the variable "animal slaughter" was the only risk factor presenting statistical significance associated with the diagnosis of $M$. bovis $(p<0.05)$, demonstrating that macroscopic lesions suspected as being caused by bovine tuberculosis from animals with an in vivo diagnosis were 2.82 - fold more likely to result in a positive M. bovis diagnosis by molecular tests.

Key words: Complex Mycobacterium tuberculosis. Nested q-PCR. Post mortem inspection. Beef.

\section{Resumo}

O Mycobacterium bovis é uma bactéria pertencente ao complexo Mycobacterium tuberculosis que causa tuberculose em bovinos e em outros animais domésticos e silvestres, bem como em humanos. As medidas de controle da doença são realizadas por meio do abate de animais com resultado positivo na prova de tuberculinização intradérmica e higienização de seus espaços de origem, além da vigilância epidemiológica realizada por meio da inspeção sanitária de carcaças bovinas em matadouros. Neste último, os serviços oficiais de fiscalização coletam amostras de lesões macroscópicas com suspeita de tuberculose bovina, que são encaminhadas para análise laboratorial. O conhecimento das variáveis associadas à ocorrência de $M$. bovis pode auxiliar na tomada de decisão quanto aos esforços de controle e erradicação da doença. Nesse contexto, o objetivo deste estudo foi identificar os fatores de risco para o diagnóstico positivo de $M$. bovis em lesões suspeitas de tuberculose bovina obtidas durante atividades de vigilância epidemiológica no estado de Mato Grosso, Brasil. Um total de 105 lesões suspeitas foram analisadas pelo método Nested Polymerase Chain Reaction (nested q-PCR), das quais 14 (13,33\%) deram positivo para M. bovis. Análises estatísticas univariadas e bivariadas indicaram que a variável "abate de animais" foi o único fator de risco com significância estatística associada ao diagnóstico de $M$. bovis $(p<0,05)$, demonstrando que lesões macroscópicas suspeitas de serem causadas por tuberculose bovina em animais com o diagnóstico in vivo teve 2,82 vezes mais probabilidade de resultar em um diagnóstico positivo para $M$. bovis por meio de testes moleculares.

Palavras-chave: Complexo Mycobacterium tuberculosis. Nested q-PCR. Inspeção post mortem. Carne bovina. 


\section{Introduction}

Bovine tuberculosis (bTB) is a low prevalence disease. However, when diagnosed, it causes economic losses by reducing sanitary status and credibility of the herds, as well as consequent meat and milk production losses (Azami \& Zinsstag, 2018).

The etiologic agent of bovine tuberculosis is Mycobacterium bovis (M. bovis), a bacterium belonging to the Mycobacterium tuberculosis Complex (CMT), distributed worlwide and affecting cattle and several mammal species, including humans. Humans acquire the infection through contact with aerosols expelled by infected animals or mainly, through the consumption of milk and dairy products not pasteurized or not heat treated from contaminated animals. It is, therefore, a serious public health problem, considered a cosmopolitan and re-emerging zoonosis (Medeiros, Marassi, Figueiredo, \& Lilenbaum, 2010; Zarden, Marassi, Carvalho, Figueiredo, \& Lilenbaum, 2013; Carvalho et al., 2016).

Epidemiological surveillance in slaughterhouses is applied in bTB monitoring, where suspicious lesions are identified and sentforlaboratory diagnosis bybacteriological and molecular tests (Araújo et al., 2014a), allowing for the tracking of remaining disease foci. In the state of Mato Grosso, Brazil, the Joint Ordinance Sedraf - INDEA/MT 009 of November 14, 2014, established mandatory collection of granulomatous lesions displaying bTB characteristics from cattle slaughtered in slaughterhouses, followed by their shipment to a laboratory indicated by the health authority and notification of the injuries to the Agricultural Defense Service (Portaria Conjunta SEDRAF-INDEA/MT n. 009, 2014).
Characterization of bTB risk factors is important to determine situations that favor the persistence of this disease in a certain locality and to define strategies for locating remaining disease foci, thus aiding local health authorities in identifying regions or properties with animals that present a greater risk of contracting or spreading the disease.

In this context, the aim of this study was to identify the risk factors concerning the occurrence of Mycobacterium bovis in macroscopic lesions suspected as being caused by bovine tuberculosis found in bovine carcasses in the state of Mato Grosso, Brazil.

\section{Material and Methods}

\section{Study area}

This study was carried out in the state of Mato Grosso, Midwestern Brazil, which is categorized into four livestock circuits as described by Negreiros et al. (2009), called CP 01 - Pantanal; CP 02 - Milk; CP 03 Fattening; CP 04 - Breeding; according to the predominant animal production characteristic, local ecosystem, and animal transit network.

\section{Sampling and zootechnical data}

A total of 105 suspected bTB lesion samples, one for each animal, were collected between September 2017 and May 2018, stored in sterile packaging and frozen during the post-mortem inspection procedure carried out in slaughterhouses in the state of Mato Grosso by Federal (SIF) (102 samples) and state (SISE/MT) (3 samples) inspection authorities using the criteria established by the regulation of inspection industrial 
and sanitary of animal products, RIISPOA (RIISPOA, 2017). If more than one lymph nodes or organ showed lesion samples the pooled samples were collected, in order to obtain a representative aliquot of each animal. Zootechnical information was also obtained during sampling, including cattle breed, sex, age group and geographic location of the animals' property of origin, for later data analysis. Simultaneously, sanitary inspection and collection of suspicious lesions were carried out following normal routine in all slaughterhouses in the state. The division of Mato Grosso state for sample collection and the variables analyzed are depicted in Figure 1.

\section{DNA extraction and quantification}

Sample preparation and DNA extraction from bovine tissue fragments containing suspicious lesions were performed according to Figueiredo et al. (2012), using the commercial Dneasy Blood and Tissue kit (Qiagen ${ }^{\circledR}$, Hilden, Germany). Following extraction, DNA was quantified by the fluorometry method using the QUBIT TM 2.0 Kit (Invitrogen ${ }^{\circledR}$, Carlsbad, CA, United States).

\section{Nested q-PCR}

Nested q-PCR was performed using the TaqMan PCR Master Mix (Applied Biosystems $^{\circledR}$, Foster City, CA, United States), primers and probe for the Rv2807 gene (Applied Biosystems ${ }^{\circledR}$, Foster City, CA, United States), specific for species belonging to the Mycobacterium tuberculosis complex (CMT) and primers and probe for the TbD1 gene (Applied Biosystems ${ }^{\circledR}$, Foster City, CA, United States), specific for M. bovis, based on the method described by Araújo et al. $(2014 a, b)$ and modified by Carvalho et al. (2015).

The Nested q-PCR reaction occurred in two stages. During the first stage, a conventional PCR was performed to amplify the Rv2807 and TbD1 regions using external primers, Forward Outer GGCGGTGGCGGAGTTGAAGGCGATGAG, Reverse Outer CATTGCTGCGTAATTCGATCA; Forward Outer TTATGGCGGCCACACCCACC CAAAACAG, Reverse Outer GACCTTGGG CGCCTCAT, respectively and template DNA at $75 \mathrm{ng}$. This reaction was prepared in a total volume of $25 \mu \mathrm{L}$ and was carried out according to the following amplification conditions: $95^{\circ} \mathrm{C}$ for 4 minutes for initial denaturation, 35 cycles at $95{ }^{\circ} \mathrm{C}$ for 90 seconds for denaturation, 60 ${ }^{\circ} \mathrm{C}$ for 30 seconds for ringing, $72{ }^{\circ} \mathrm{C}$ for 45 seconds for extension and a final extension step carried out at $72^{\circ} \mathrm{C}$ for 3 minutes. 


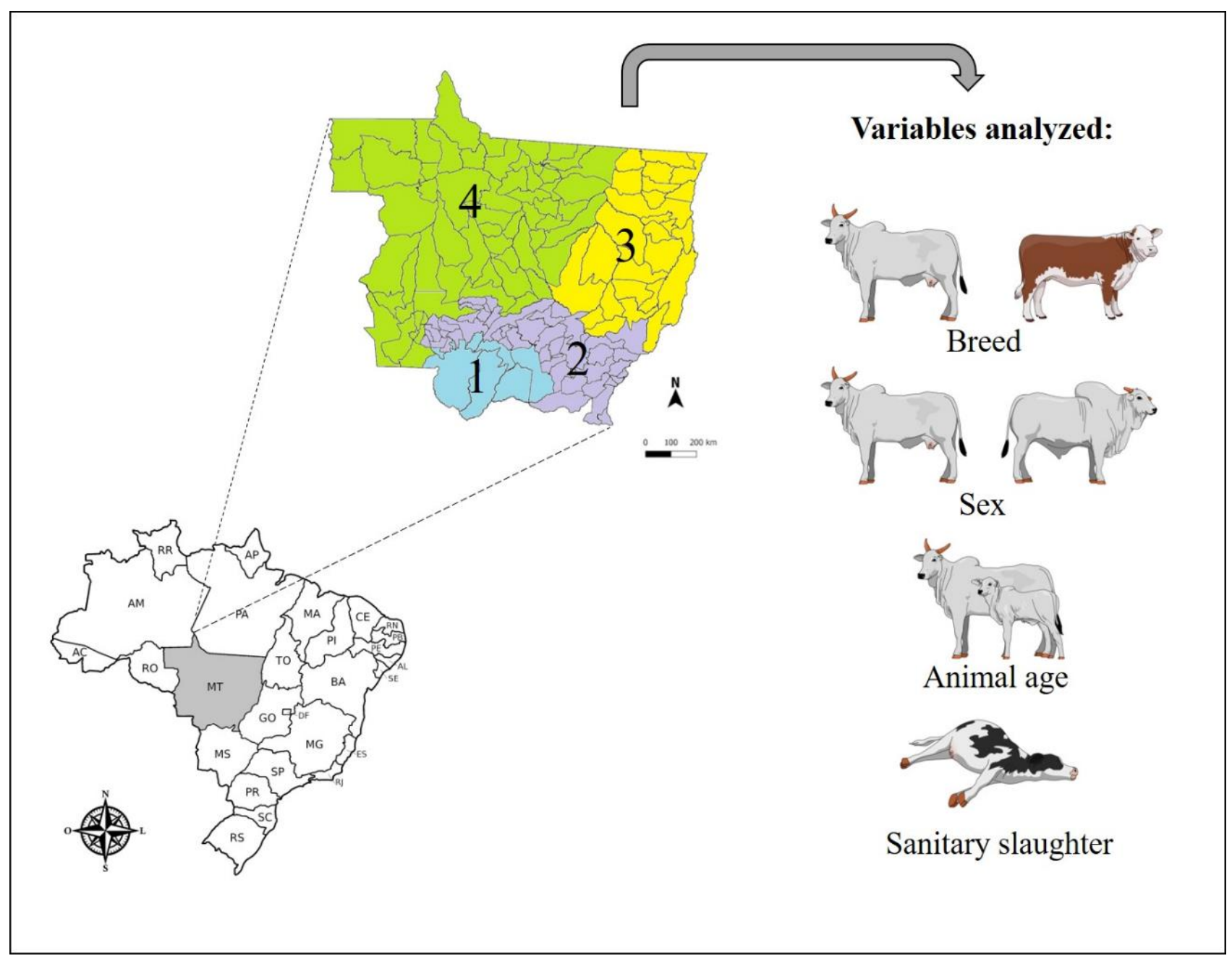

Figure 1. Experimental design of the study and division of the type of animal production in the state of Mato Grosso.

Legend: The state division was represented according to the predominant animal production characteristic, local ecosystem, and animal transit network. The division was proposed by Negreiros et al. (2009). Numbers represent: 1 - Pantanal, 2 - Milk, 3 - Fattening, and 4 - Breeding. 
During the second stage of the reaction, a nested q-PCR was performed to amplify the Rv2807 and TbD1 regions using internal primers, TaqMan probe, Forward Internal CATTGCTGCGTAATTCGATCA, Reverse Internal GACCTTGGGCGCCTCAT, Probe 6FAM CATCCACACCTGTTCGMGBNFQ; Forward Internal GCGGTCTTCGCCAATGTT, Reverse Internal GCAGCCGATGGAATTGCT, Probe 6FAM TCGCGCAAGGCGA MGBNFQ, respectively and $3 \mu \mathrm{L}$ of the amplicon obtained during the first stage. This reaction was prepared in a total volume of $12.5 \mu \mathrm{L}$ and carried out according to the following amplification conditions: $95^{\circ} \mathrm{C}$ for 10 minutes for initial denaturation and 35 cycles at $95^{\circ} \mathrm{C}$ for 15 seconds for denaturation and $60{ }^{\circ} \mathrm{C}$ for 30 seconds for annealing/extension.

\section{Data analysis}

For the statistical and descriptive analyses, the information contained in the lesion receiving forms was considered, comprising breed, sex, age group, geographic location, and sanitary slaughter. The breed variable comprised two categories, Zebu and other breeds, the age group variable was formed by the categories 12 - 24 months, 24 - 36 months and > 36 months, variable geographic location comprised the livestock circuit categories 01 to 04, and the variable slaughter was composed of categories YES (positive animals in the intradermal tuberculinization test) and NO (animals without an in vivo diagnosis).

A descriptive analysis of the sample variables and a bivariate analysis for the molecular M. bovis diagnosis using Fisher's exact test, chi-square tests and the crude prevalence ratio, with a 95\% confidence interval and a significance level of less than $5 \%(p<0.05)$, were performed. The variables associated by the chi-square test were selected to adjust a Poisson regression model. The SPSS ${ }^{\circledR}$ Software (v. 20) was used for all statistical analyses.

\section{Results and Discussion}

\section{Univariate analysis}

A univariate analysis (Table 1) was applied to indicate the probability of 105 suspected bTB lesions harvested from cattle in the state of Mato Grosso to be associated with one of the established variables, i.e., sex, breed, age group, livestock circuit, slaughter, and a molecular diagnosis of M. bovis.

From the total of 105 suspected bTB lesions collected according official judgment criteria (RIISPOA, 2017; Mato Grosso, 2014) 86.67\% (91/105) [IC95\%: 78.64 - 92.51] tested negative for $M$. bovis and $13.33 \%(14 / 105)$ [IC95\%: 7.49 - 21.36] tested positive.

Of the total of suspected injuries, 65.71\% [IC95\%: 55.81 - 74.70] were from male cattle and 34.29\% [IC95\%: 25.30 44.19] from females. Regarding breed, $81.9 \%$ [IC95\%: 73.19 - 88.74] of the suspected bTB lesions were obtained from zebu cattle, while 18.11\% [IC95\%: 11.26 - 26.81] were from other categories. With regard to age group, and 19.05\% [IC95\%: 12.0 - 27.87] of the suspected bTB lesions were obtained from cattle aged 12 to 24 months, $45.71 \%$ [IC95\%: 35.96 - 55.72], from individuals aged 24 to 36 months and 35.24\% [IC95\%: 26.16 - 45.17] from animals over 36 months (Table 1). 


\section{Table 1}

Frequency and distribution analysis of 105 suspected bovine tuberculosis lesions collected from cattle in the state of Mato Grosso, Brazil. Frequency, percentage and $95 \%$ confidence intervals for the variables sex, breed, age group, livestock circuit, slaughter, as well as molecular diagnosis of Mycobacterium bovis, from September 2017 to May 2018

\begin{tabular}{|c|c|c|c|}
\hline Variable & $\begin{array}{c}\text { Frequency } \\
(\mathrm{n}=105)\end{array}$ & Percentage (\%) & $95 \% \mathrm{Cl}$ \\
\hline \multicolumn{4}{|l|}{ Sex } \\
\hline Female & 36 & 34.29 & $(25.30-44.19)$ \\
\hline Male & 69 & 65.71 & $(55.81-74.70)$ \\
\hline \multicolumn{4}{|l|}{ Bovine species } \\
\hline Zebu & 86 & 81.90 & $(73.19-88.74)$ \\
\hline Others & 19 & 18.11 & $(11.26-26.81)$ \\
\hline \multicolumn{4}{|l|}{ Age range } \\
\hline 12 - 24 months & 20 & 19.05 & $(12.04-27.87)$ \\
\hline 24 - 36 months & 48 & 45.71 & $(35.96-55.72)$ \\
\hline$>36$ months & 37 & 35.24 & $(26.16-45.17)$ \\
\hline \multicolumn{4}{|l|}{ Livestock circuit } \\
\hline CP 01 (Pantanal) & 12 & 11.43 & $(6.05-19.11)$ \\
\hline CP 02 (milk) & 25 & 23.81 & $(16.04-33.11)$ \\
\hline CP 03 (Fattening) & 1 & 1.0 & $(0.02-5.19)$ \\
\hline CP 04 (Breeding) & 67 & 63.8 & $(53.86-72.96)$ \\
\hline \multicolumn{4}{|l|}{ Sanitary slaughter } \\
\hline No & 98 & 93.33 & (86.74 - 97.28) \\
\hline Yes & 7 & 6.67 & $(2.72-13.25)$ \\
\hline \multicolumn{4}{|c|}{ Molecular M. bovis diagnosis } \\
\hline Negative & 91 & 86.67 & $(78.64-92.51)$ \\
\hline Positive & 14 & 13.33 & $(7.49-21.36)$ \\
\hline
\end{tabular}

95\% Cl: Confidence Interval 95\%.; CP: Livestock Circuit.

The stratification concerning livestock circuit origin indicated that $63.8 \%$ [IC95\%: 53.86 - 72.96] of the suspected bTB lesions originated from the livestock breeding circuit (CP 04), followed by the milk breeding circuit (CP 02), at 23.81\% [IC95\%: $16.04-33.11]$, Pantanal livestock circuit (CP 01), 11.43\% [IC95\%: 6.05 - 19.11] and fattening livestock circuit (CP 03), 0,95\% [IC95\%: 0.02 - 5.19]. The health slaughter variable indicated that only 6.67\% [IC95\%: 2.72 - 13.25] of the suspected bTB lesions were obtained from animals sent for slaughter, while 93.33\% [IC95\%: 86.74 - 97.28] of the harvested lesions came from commercial slaughter (Table 1). 


\section{Bivariate Analysis}

The associations between the molecular $M$. bovis diagnosis results and the other independent variables, identified by a bivariate analysis, allowed for the determination that health slaughter $(p=0.048)$ was the only variable presenting statistical significance $(p<0.05)$ (Table 2).

An analysis of the regression model of the equation indicated that the only risk factor associated with $M$. bovis diagnosis was health slaughter ( $p<0.05$ ), due to a statistically significant difference (Table 2), indicating the positivity of suspicious bTB lesions from bovines tested positive to the intradermal tuberculin skin test.

The present study considered the risk factors associated with slaughtered cattle variables and the stratification of the property of origin of animals presenting suspicious lesions for bTB in the state of Mato Grosso. The univariate analysis concerning sex indicated a statistically significant difference. However, when performing the bivariate analysis, this variable became nonstatistically different, demonstrating that samples with suspicious lesions collected by the bTB surveillance service do not display an associated positive diagnostic relationship to sex. This corroborates the results described by several authors (Biffa, Bogale, Godfroid, \& Skjerve, 2011; Clegg, Good, \& More, 2016; Okeke et al., 2014; Pascual-Linaza, Gordon, Stringer, \& Menzies, 2017).

Regarding the univariate analysis, lesions obtained from zebu cattle were statistically different compared to other breeds. However, the bivariate analysis indicated no significant association between zebu breeds and other breeds, most likely due to the fact that meat production in the state of Mato Grosso is mainly of zebu cattle, which is more representative in the sampling due to of the amount of cattle sent for slaughter during the study period. Similarly, studies carried out in Nigeria indicated no statistically significant differences concerning positive $M$. bovis diagnoses associated with breed, thus corroborating the results obtained herein (Akinseye, Adebayo, Genesis, Adelakun, \& Cadmus, 2018; Okeke et al., 2014).

A statistically significant difference in the univariate analysis concerning suspicious lesions associated with age group was observed only between 12 - 24 months and 24 - 36 months, and no statistically significant difference between these two age groups were observed in relation to $>36$ months. However, the bivariate analysis demonstrated that the age group variable was not significantly associated to lesion positivity for M. bovis, similar to that reported by Okeke et al. (2014) in Nigeria. Other authors described statistically significant difference, pointing to a higher risk of positive bTB lesions associated with older animals (Akinseye et al., 2018; Biffa et al., 2011; Boukary et al., 2012; PascualLinaza et al., 2017). Other reports associated young animals to a higher frequency of severe bTB lesions (Biffa, Bogale, Godfroid, \& Skjerve 2012), demonstrating that lesions obtained from older animals are less likely to test positive for M. bovis (Shittu, Clifton-Hadley, Ely, Upton, \& Downs 2013). 


\section{Table 2}

Frequency distribution and prevalence ratio concerning the occurrence of Mycobacterium bovis by variable, in suspected lesion obtained from the epidemiological surveillance regarding bovine tuberculosis in the state of Mato Grosso, from September 2017 to May 2018

\begin{tabular}{|c|c|c|c|c|c|c|c|c|}
\hline \multirow{2}{*}{ Variable } & \multirow{2}{*}{ Category } & \multicolumn{4}{|c|}{ M. bovis results } & \multirow{2}{*}{$\mathrm{RPb}$} & \multirow{2}{*}{$95 \% \mathrm{Cl}$} & \multirow{2}{*}{$p<0.05$} \\
\hline & & $\mathrm{N}^{\circ} \mathrm{Pos}$ & $\%$ & $\mathrm{~N}^{\circ} \mathrm{Neg}$ & $\%$ & & & \\
\hline \multirow{2}{*}{ Sex } & Female & 6 & 16.7 & 30 & 83.3 & 1.43 & $(0.54-3.83)$ & $0.549^{*}$ \\
\hline & Male & 8 & 11.6 & 61 & 88.4 & 1.00 & & \\
\hline \multirow{2}{*}{ Breed } & Zebu & 12 & 13.9 & 74 & 86.1 & 1.32 & $(0.32-5.44)$ & $1.0^{*}$ \\
\hline & Others & 2 & 10.5 & 17 & 89.5 & 1.0 & & \\
\hline \multirow{2}{*}{ Age Range } & $>36$ months & 6 & 16.2 & 31 & 83.8 & 1.38 & $(0.52-3.67)$ & $0.557^{*}$ \\
\hline & $\leq 36$ months & 8 & 11.8 & 60 & 88.2 & 1.00 & & \\
\hline \multirow{2}{*}{$\begin{array}{l}\text { Livestock } \\
\text { circuit }\end{array}$} & CP 02 (milk) & 5 & 20.0 & 9 & 80.0 & 1.49 & $(0.55-4.02)$ & $0.515^{*}$ \\
\hline & CP 04 (Breeding) & 9 & 13.4 & 58 & 86.6 & 1.00 & & \\
\hline \multirow{2}{*}{$\begin{array}{l}\text { Sanitary } \\
\text { slaughter }\end{array}$} & Yes & 3 & 42.9 & 4 & 57.1 & 3.82 & $(1.38-10.60)$ & $0.048 \#$ \\
\hline & No & 11 & 11.2 & 87 & 86.7 & 1.00 & & \\
\hline
\end{tabular}

* Fisher's exact test; ** chi-square test for 2 x 2 type table; RPb: Prevalence Ratio or Risk; Pos.: Positive; Neg.: Negative; p: p-value (<0.005); 95\% Cl: 95\% confidence interval; CP: Livestock Circuit; \# statistical significance $(p<0.05)$.

The univariate analysis regarding livestock circuits indicated no statistically significant difference in the frequency of injuries obtained from CP 01 and CP 02, and a statistically significant difference between the CP 03 and CP 04 circuits. In the bivariate analysis, however, no significant difference was observed among the livestock circuits, despite the constant frequency of bTB outbreaks in CP 02 (Milk) and CP 04 (Breeding). The bTB outbreaks were associated with dairy properties, where the health problem was attributed to greater animal density and long production cycles, corroborating Néspoli et al. (2016).

The health slaughter variable was statistically different concerning injuries obtained from animals positive for bTB (07/105) and animals commercially sent for slaughter (98/105) in the univariate analysis.
In the bivariate analysis, slaughter was the only statistically different $(p<0.05)$ variable, indicating thatanimals withapositive diagnosis for bTB (positive for in vivo diagnosis) were 2.82 - fold more likely to present suggestive lesions confirmed as being caused by bTB by the nested q-PCR test.

Regarding the descriptive statistical analysis, $42.86 \%(07 / 03)$ of the injuries originating from slaughtered animals (07/105), were confirmed as positive for the molecular diagnosis of $M$. bovis. Cazola et al. (2015) reported that, from a total of 13 cattle positive in the intradermal test, $84.6 \%(11 / 13)$ were confirmed for $M$. bovis by the bacterial culture method (Cazola et al., 2015), demonstrating a high rate of disease confirmation. Fráguas et al. (2008) indicated that, from a total of 97 bovine animals reactive to the intradermal test, only $11.34 \%(11 / 97)$ were confirmed as 
M. bovis in bacterial cultures and postulated that this low bacterial recovery rate may be related to the difficulty of carrying out $M$. bovis cultures, which requires a minimum amount of viable bacilli, in addition to a decontamination technique applied during the process that can render this microorganism unfeasible.

Zarden et al. (2013) followed the slaughter of 24 cattle reactive to the tuberculin skin test, with $29.16 \%(n=7)$ presenting suspicious lesions for bTB. When submitting samples without lesions for laboratory analysis, it was found that $73.16 \%$ ( $n=19$ ) of the animals tested positive when using bacterial culture, while $75.16 \%(n=18)$ tested positive by the molecular method. The authors concluded that the combination of these methods increased sensitivity and specificity, with $95.8 \%(n=23)$ of the animals testing positive for $M$. bovis, reinforcing that inconclusive tuberculinization results presented greater diagnosis chances through suspicious lesions. Figueiredo et al. (2009) performed a pool of samples of individual macroscopic lesions from 34 animals reactive to the tuberculin skin test and obtained a $50 \%$ ( $n=17$ ) positive diagnosis in the bacterial culture method, with $88.24 \%$ ( $n=15$ ) of the samples confirmed through multiplex-PCR.

Araújo et al. (2014a) collected 80 lesion samples from animals reactive to the intradermal tuberculin skin test, and observed presence of $M$. bovis DNA in $61.25 \%(n=49)$ by the nested-PCR technique, with a greater number of animals testing positive for the pathogenic agent when compared to bacterial culture in the group of animals without information or without tuberculin tests $(p<$ 0.05), that is, animals that were commercially sent to slaughter and observed as presenting lesions in the sanitary inspection line.
Risk factors may vary between surveys, due to regional differences, such as bTB prevalence, climatic variation, breed characteristics, management, production cycle, degree of property technification and strains. Each region may present intrinsic risk factors that must be considered when applying risk-based surveillance strategies, providing better resource application, and promoting improvements in local agricultural defense management.

\section{Conclusion}

Therefore, taking into account that sex, breed, age group and livestock circuit were not significantly different or associated with factors that influence the diagnosis of bTB in the state of Mato Grosso and that slaughter sanitary conditions were statistically different $(p<0.05)$ in confirming the diagnosis of bovine tuberculosis, a greater investment in the in vivo diagnosis of the disease is suggested, as a way of increasing the chances of identifying and tracking new bovine tuberculosis foci in the state of Mato Grosso.

Moreover, the combination of intradermal tuberculin and molecular diagnostic tests potentiates the identification of $M$. bovis and the location of remaining disease foci, suggesting that the adopted strategy is appropriate for maintaining the health profile of the state of Mato Grosso.

\section{Acknowledgements}

The authors are grateful to INDEA, Mato Grosso, Brazil, for the partnership in providing bovine samples suspected of having bovine tuberculosis. 


\section{Funding}

The authors also acknowledge financial support from the Fundação de Amparo a Pesquisa do Estado de Mato Grosso (Foundation for Research Support in Mato Grosso State) FAPEMAT Grant No. 366047/2017, and National Council for Scientific and Technological - CNPq (Grant No. 151336/2020-2 and 310462/2018-5).

\section{Conflict of interest}

The authors declare that they have no conflicts of interest.

\section{Ethic approval}

The project was approved by the Committee on Ethics in Animal Use of Federal University of Mato Grosso (CEUA protocol 23108.226903/2017-72).

\section{References}

Akinseye, V. O., Adebayo, M. D., Genesis, O. O., Adelakun, O. D., \& Cadmus, S. I. (2018). Prevalence and risk factors of mycobacterial infections in farm and trade cattle in southwestern Nigeria. Tropical Animal Health and Production, 50(4), 761772. doi: 10.1007/s11250-017-1492-4

Araújo, C. P., Osorio, A. L. A., Jorge, K. S., Ramos, C. A. N., Francisco, S. A. Fo., Vidal, C. E. S.,... Araújo, F. R. (2014a). Detection of Mycobacterium bovis in bovine and bubaline tissues using nested-PCR for TbD1. PLoS One, 9(3). doi: 10.1371/ journal.pone.0091023
Araújo, C. P., Osório, A. L. A., Jorge, K. S., Ramos, C. A., Souza, A. F. Fo., Vidal, C. E.,... Araújo, F. R. (2014b). Direct detection of Mycobacterium tuberculosis complex in bovine and bubaline tissues through nested-PCR. Brazilian Journal of Microbiology, 45(2), 633-640. doi: 10.1590/S1517-83822014000200035

Azami, H. Y., \& Zinsstag, J. (2018). Economics of bovine tuberculosis: a one-healt issue. In M. Chambers, S. Gordon, F. Olea-Popelka, \& P. Barrow (Orgs.), Bovine tuberculosis (cap. 3, p. 31-42). London, UK: British Library.

Biffa, D., Inangolet, F., Bogale, A., Oloya, J., Djønne, B., \& Skjerve, E. (2011). Risk factors associated with prevalence of tuberculosis-like lesions and associated mycobacteria in cattle slaughtered at public and export abattoirs in Ethiopia. Tropical Animal Health and Production, 43(2), 529-538. doi: 10.1007/s11250010-9729-5

Biffa, D., Bogale, A., Godfroid, J., \& Skjerve, E. (2012). Factors associated with severity of bovine tuberculosis in Ethiopian cattle. Tropical Animal Health and Production, 44(5), 991-998. doi: 10.1007/s11250011-0031-y

Boukary, A. R., Thys, E., Rigouts, L., Matthys, F., Berkvens, D., Mahamadou, I.,... Saegerman, C. (2012). Risk factors associated with bovine tuberculosis and molecular characterization of Mycobacterium bovis strains in urban settings in Niger. Transboundary and Emerging Diseases, 59(6), 490-502. doi: $10.1111 / j .1865-1682.2011 .01302 . x$

RIISPOA (2017). Regulamento da Inspeção Industrial e Sanitária de Produtos 
de Origem Animal (RIISPOA). Ministério da Agricultura, Pecuária e Abastecimento. Recuperado de https://www.gov.br/agricultura/pt-br/ assuntos/inspecao/produtos-animal/ arquivos/decreto-n-9013-2017_Itdecreto-9069-20 17_pt.pdf/view

Carvalho, R. C. T., Furlanetto, L. V., Maruyama, F. H., Araújo, C. P. de, Barros, S. L. B., Nascimento Ramos, C. A. do,... Figueiredo, E. E. S. (2015). Evaluation of the efficiency of nested q-PCR in the detection of Mycobacterium tuberculosis complex directly from tuberculosis-suspected lesions in post-mortem macroscopic inspections of bovine carcasses slaughtered in the state of Mato Grosso, Brazil. Meat Science, 106, 11-15. doi: 10. 1016/j.meatsci.2015.03.017

Carvalho, R. C. T., Vasconcellos, S. E. G., Azevedo, I. S. S. A. de M., Soares, P. M., Fo., Mota, P. M. P. C., Araújo, F. R. de,... Paschoalin, V. M. F. (2016). Molecular typing of Mycobacterium bovis from cattle reared in Midwest Brazil. PloS One, 11(9), 1-16. doi: 10.1371/journal.pone.0162459

Cazola, D. D. O., Jorge, K. D. S., Zumárraga, M. J., Souza, A. F., Fo., Araújo, F. R., \& Osório, A. L. A. (2015). Identificação e genotipagem de Mycobacterium bovis em bovinos positivos no teste intradérmico para tuberculose em Mato Grosso do Sul. Pesquisa Veterinária Brasileira, 35(2), 141-147. doi: 10.1590/ S0100-736X2015000200008

Clegg, T. A., Good, M., \& More, S. J. (2016). Risk factors for cattle presenting with a confirmed bTB lesion at slaughter, from herds with no evidence of within-herd transmission. Preventive Veterinary Medicine, 126(1), 111-120. doi: 10.1016/j. prevetmed.2016.02.003

Figueiredo, E. E. de S., Silvestre, F. G., Campos, W. N., Furlanetto, L. V., Medeiros, L., Lilenbaum, W.,... Paschoalin, V. M. F. (2009). Identification of Mycobacterium bovis isolates by a multiplex PCR. Brazilian Journal of Microbiology, 4O(2), 231-233. doi: 10.1590/S1517-838220 09000200004

Figueiredo, E. E. de S., Conte-Junior, C. A., Furlanetto, L. V., Silva, F. G. S., Duarte, R. S., Silva, J. T.,... Paschoalin, V. M. F. (2012). Molecular techniques for identification of species of the Mycobacterium tuberculosis complex: the use of multiplex PCR and an adapted HPLC method for identification of Mycobacterium bovis and diagnosis of bovine tuberculosis. In P.-J. Cardona (Ed.), Understanding tuberculosis: global experiences and innovative approaches to the diagnosis (pp. 411-432). InTech Open.

Fráguas, A.S., Cunha-Abreu, M. S., Reis Ferreira, A. M. dos, Marassi, C. D., Oelemann, W., Souza Fonseca, L. de,... Lilenbaum, W. (2008). Estudo comparativo de métodos complementares para o diagnóstico da tuberculose bovina em animais reagentes à tuberculinização. Revista Brasileira de Ciência Veterinária, 15(3), 117-121. doi: 10.4322/rbcv.2014.211 Recuperado de https://periodicos.uff.br/rbcv/article/view 17073

Portaria Conjunta SEDRAF-INDEA/MT n. 009 (2014). Portaria Conjunta SEDRAFINDEA/MT n. 009, 14 de novembro de 2014. Institui o regulamento técnico do 
plano de vigilância para a Erradicação da Tuberculose bovina no Estado de Mato Grosso e cria o Programa Estadual de Submissão de Granuloma do Estado de Mato Grosso. Diário Oficial do Estado de Mato Grosso. Cuiabá, MT, 13 nov. 2014. Recuperado de https://www.legisweb. com.br/ legislacao/? id $=276860$

Medeiros, L. D. S., Marassi, C. D., Figueiredo, E. E. S., \& Lilenbaum, W. (2010). Potential application of new diagnostic methods for controlling bovine tuberculosis in Brazil. Brazilian Journal of Microbiology, 41(3), 531-541. doi: 10.1590/S1517-838 22010005000002

Negreiros, R. L., Dias, R. A., Ferreira, F., Ferreira, J. S., Neto, Gonçalves, V. S. P., Silva, M. D. C. P.,... Amaku, M. (2009). Situação epidemiológica da brucelose bovina no Estado de Mato Grosso. Arquivo Brasileiro de Medicina Veterinária e Zootecnia, 61(1), 56-65. doi: 10.1590/S01 02-09352009000700007

Néspoli, J. M. B., Negreiros, R. L., Amaku, M., Dias, R. A., Ferreira, F., Telles, E. O., Ferreira, J. S. Neto. (2016). Epidemiological situation of bovine tuberculosis in the state of Mato Grosso, Brazil. Semina: Ciências Agrárias, 37(5), 3589-3599. doi:10.5433/1679-03 59.2016 v37n5Supl2p3589
Okeke, L. A., Cadmus, S., Okeke, I. O., Muhammad, M., Awoloh, O., Dairo, D.,... Fawole, O. (2014). Prevalence and risk factors of Mycobacterium tuberculosis complex infection in slaughtered cattle at Jos South Abattoir, Plateau State, Nigeria. The Pan African Medical Journal, 18(Suppl. 1), 1-5, doi: 10.11694/pamj. supp.2014.18.1.3841

Pascual-Linaza, A. V., Gordon, A. W., Stringer, L. A., \& Menzies, F. D. (2017). Efficiency of slaughterhouse surveillance for the detection of bovine tuberculosis in cattle in Northern Ireland. Epidemiology \& Infection, 145(5), 995-1005. doi: 10.1017/ S0950268816003095

Shittu, A., Clifton-Hadley, R. S., Ely, E. R., Upton, P. U., \& Downs, S. H. (2013). Factors associated with bovine tuberculosis confirmation rates in suspect lesions found in cattle at routine slaughter in Great Britain, 2003-2008. Preventive Veterinary Medicine, 110(3-4), 395-404. doi: 10.1016/j.prevetmed.2013.03.001

Zarden, C. F. O., Marassi, C. D., Carvalho, A. C., Figueiredo, E. E. S., \& Lilenbaum, W. (2013). Bacteriological and molecular detection of Mycobacterium bovis in cattle with inconclusive results to intradermal tuberculin tests. Epidemiology \& Infection, 141(7), 1390-1393. doi: 10.1017/S0950 268812002105 
